Metallurgical Investigations of Iron Wares

\title{
in Ancient Japan
}

\author{
By Kazuo Horikawa ${ }^{* *}$ and Yoshinobu Umezawa ${ }^{* * *}$
}

\section{Synopsis}

Metallurgical investigation of ancient iron nails, clamps, rivets and other objects used in several old wooden buildings in Japan such as "Horyuji" temple has been carried out.

\section{Introduction}

Metallurgical investigation of iron wares made in Japan in ancient times has been performed in detail by Dr. Kuniichi Tawara ${ }^{1)}$ on Japanese swords. The results of these investigations have been highly evaluated in Japan as one of the most valuable achievements in iron metallurgy.

Investigations were performed by Dr. Nishimura et al.2) on pieces of ancient iron ware. Among these were nails used in "Kondo" (main hall) and the five-story pagoda of "Horyuji" temple. These are almost the only detailed studies available, because the specimens are classified as valuable cultural properties and are difficult to obtain.

The authors were asked by Tokyo National Institute of Cultural Properties to make metallurgical investigations on about 50 nails, clamps, rivets, ornaments and other wares taken from "Horyuji," the oldest wooden building in the world, and "Daigoji," "Meitsuji," and other old temples.

The results of this investigation have both historical and technical interests and are of technical value for the engineers engaged in the iron and steel industry. The outline of the results of this investigation is reported as follows.

\section{Nails}

\section{Specimens Investigated}

Specimens presented for this investigation included the following twenty-eight pieces: six pieces taken from "Kondo" (main hall) of "Horyuji" temple, ten pieces from "Hoodo" (sanctuary) of "Byodoin" temple, two pieces from the three-story pagoda of "Meitsuji" temple, six pieces from the five-story pagoda of "Daigoji" temple and four pieces from the oratory of "Otonashi" shrine. The times of their manufacture are estimated to be in the years from 607 to 1800 A.D. The external appearances of the representative specimens are shown in Photo 1.

H-3 was made in 1283 A.D. and its head was made by striking one end of the trunk flatly and then by bending it. H-4 was made in 1603 A.D. and it gives a delicate impression with its slender trunk and thin head. H-5, small-sized nail which is presumed to have been made between 1690 and 1833
A.D., has a similar appearance to those of today.

Nails B-1 to B-9, which were taken from the sanctuary of "Byodoin" temple, were made in 1053 A.D. B-1 B-5 give impressions of being broad and strong, while B-6 B-9 give impressions of being slender and delicate. B-10 made in 1670 A.D. is $290 \mathrm{~mm}$ in length.

Both M-1 (small nail) and M-2 (long nail) taken from the three-story pagoda of "Meitsuji" temple are supposed to have been made in about 1450 A.D. or in a somewhat later age.

D-1 and D-2 taken from the five-story pagoda of "Daigoji" temple were made in 953 A.D. The latter is for joining gate leaves. Those from D-3 to D-6 are estimated to have been made in about 1770 A.D. The trunk parts are thick and the end parts are slender.

Those from $\mathrm{O}-1$ to $\mathrm{O}-4$, were taken from the oratory of "Otonashi" shrine, and were made in 1663 A.D. They are only 55 to $75 \mathrm{~mm}$ in length.

\section{Chemical Compositions}

The results of chemical analysis of these specimens are shown in Table 1 . The carbon content lies within the range of $0.08-0.45 \%$, but as mentioned afterwards, it varies markedly depending upon the position even in the same specimen, so that abovementioned numbers only show roughly mean value.

The Si content varies depending upon the specimens and exists in the form of iron slag. The Mn content is extremely low excepting the case of H-4 with $0.23 \% \mathrm{Mn}$. The $\mathrm{P}$ content disperses within the limit of $0.007 \sim 0.174 \%$ depending upon the different specimens. The $\mathrm{S}$ content is very low such as under $0.009 \%$ with one or two exceptions. The $\mathrm{Cu}, \mathrm{Ni}$ and $\mathrm{Cr}$ contents are respectively under $0.03 \%, 0.07 \%$ and $0.01 \%$ with a few exceptions. The $\mathrm{N}$ content is roughly the same as that of open hearth steel, but the $\mathrm{O}$ content is remarkably high due to much iron slag inclusion.

According to the results of spectrographic analysis, even traces of $\mathrm{As}, \mathrm{Ca}, \mathrm{Co}, \mathrm{Mo}, \mathrm{Pb}, \mathrm{Sn}, \mathrm{V}$ and $\mathrm{Zn}$ could not be recognized.

\section{Microstructure}

One of the special features of ancient nails is conspicuous unevenness in microstructure even with the same specimen. The result of inspection with a metallurgical microscope from one end to the other on the cross section at the central part in the longitudinal direction of $\mathrm{H}-3$ specimen is as

* Lecture delivered before the 61st Grand Lecture Meeting of the Iron \& Steel Institute of Japan on April 3, 1961 in Tokyo. Japanese text was printed in "Tetsu-to-Hagané" (Journal, Iron \& Steel Institute, Japan) Vol. 47, No. 3, pp. 418-420.

** Dr. Eng., Technical Research Inst., Nippon Kokan Kabushiki Kaisha.

**** Technical Research Inst., Nippon Kokan Kabushiki Kaisha. 


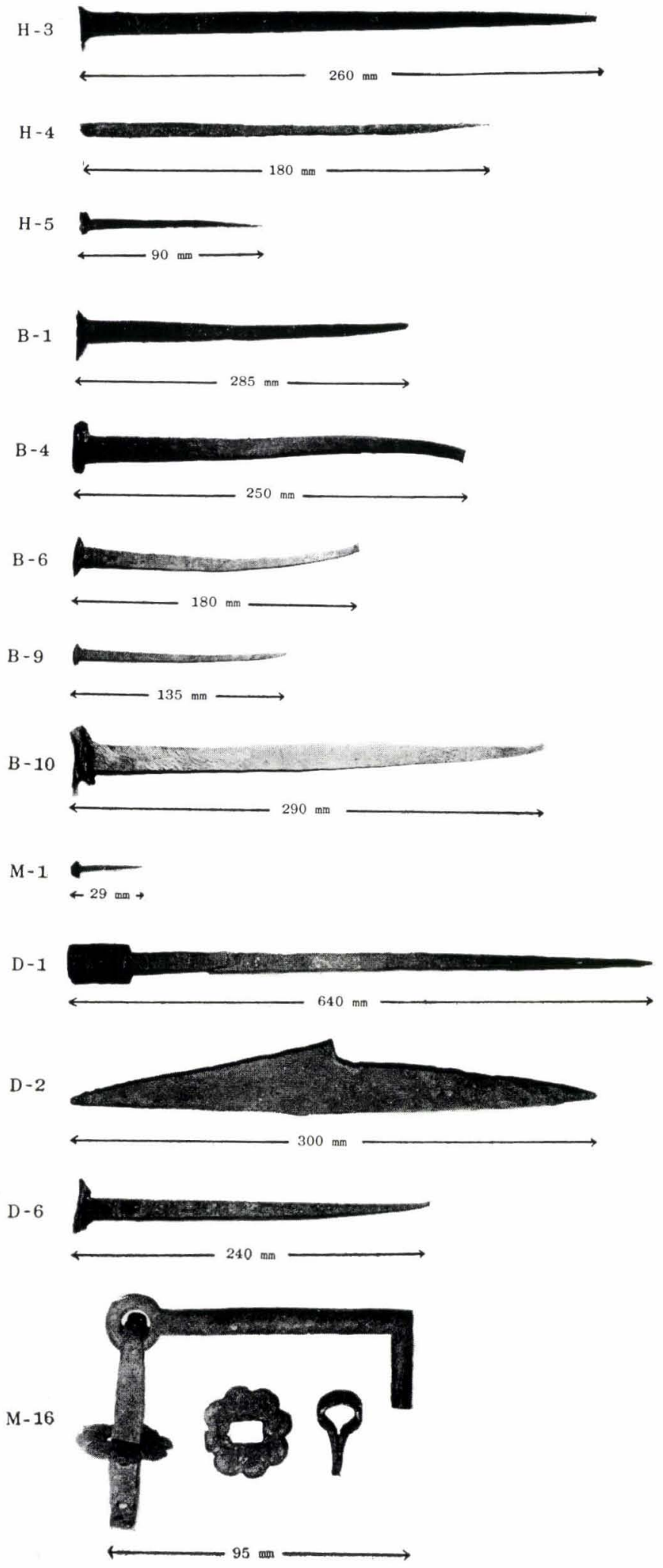

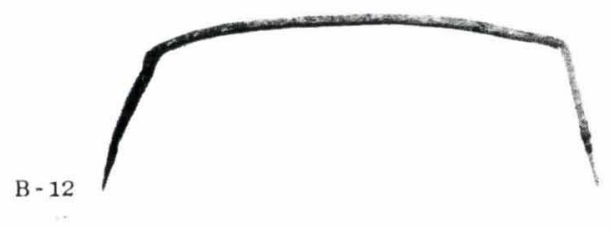

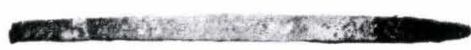

235
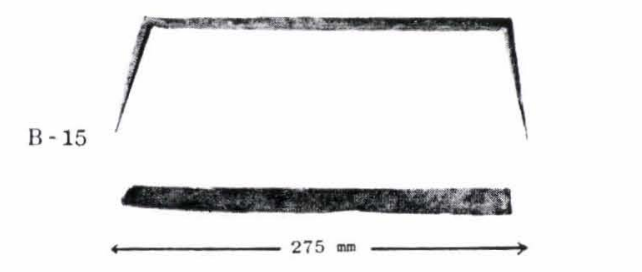

B - 16
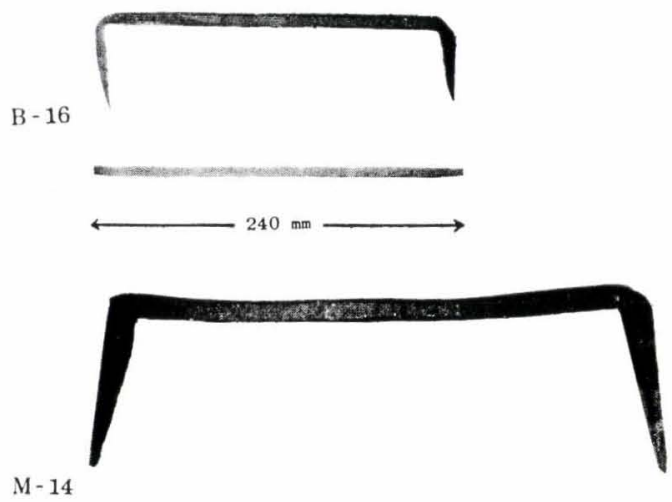

$\mathrm{M}-1$
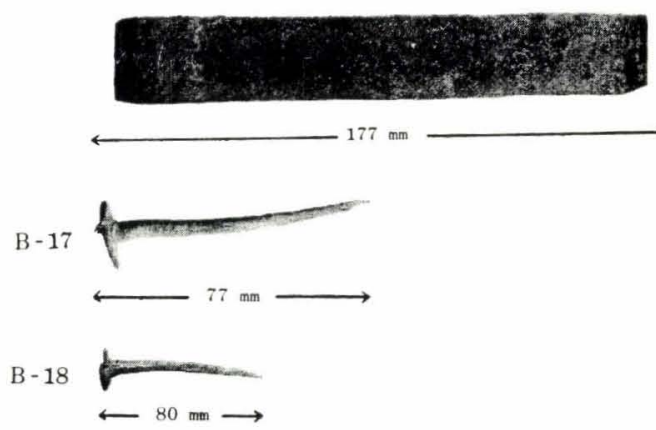

M- 15
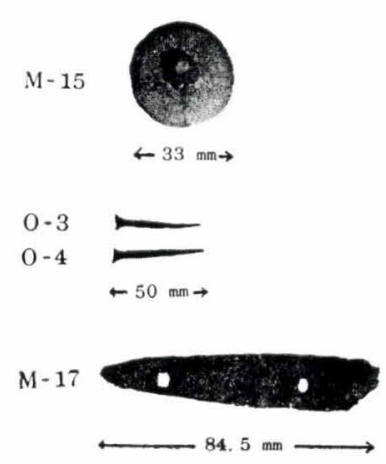

Photo 1. Outside appearance of the representative specimens 
shown in Photo 2.

It is presumed that $\mathrm{H}-3$ specimen was made by forging several pieces of crude iron which have different $\mathrm{C}$ content. The result of investigation on the carbon distribution is illustrated in Fig. 1 in conformity to Photo 3 for convenience. In each specimen, the structure of different $\mathrm{C}$ content runs longitudinally, and the larger the size of specimen is and the older the period of its manufacture, the more remarkable is the unevenness in structure. But the $\mathrm{C}$ content does not seem to be controlled intentionally depending on the positions such as the core, the outside layer, the head or trunk. Microstructure of typical specimens is shown in Photo 4.

\section{Nonmetallic Inclusions}

Many nonmetallic inclusions exist in ancient nails. The result of measuring the area ratio by point-counting method is shown in Table 1 . The results of microscopic investigation of the specimen show a structure as Photo 4 and the result of analysis indicates that it is mainly composed of silicate of iron as shown in Table 2.

\section{Hardness}

The result of measuring the hardness of each specimen shows that there is unevenness due to uneven structure in the same specimen. The range of measured hardness is shown in Table 1. As a result of detecting austenitic grain size by carburizing method, the part of low carbon has shown an abnormal structure and that of high carbon has shown Nos. 1 3 in grain size number established by A.S.T.M.

\section{Clamps}

\section{Specimens Investigated}

Investigation has been conducted on ten specimens including six pieces taken from "Hoodo" (sanctuary) of "Byodoin" temple and four pieces taken from three-story pagoda of "Meitsuji” temple.

B-11 and B-12 were made in $1053, \mathrm{~B}-13$ in 1180 -

Table 2. Results of chemical analysis of nonmetallic inclusions in the specimen in percentages hot nitric-acid method

\begin{tabular}{|c|c|c|c|c|c|c|}
\hline Specimen No. & $\mathrm{SiO}_{2}$ & $\mathrm{Al}_{2} \mathrm{O}_{3}$ & $\mathrm{FeO}$ & $\mathrm{MnO}$ & $\mathrm{TiO}_{2}$ & Total \\
\hline $\mathrm{H}-1$ & 0.059 & 0.014 & 0.003 & $\operatorname{tr}$ & 0.001 & 0.077 \\
\hline B -1 & 0.027 & 0.005 & 0.015 & " & - & 0.047 \\
\hline B-4 & 0.025 & 0.009 & 0.047 & $"$ & 0.026 & 0.125 \\
\hline B-10 & 0.030 & 0.006 & 0.049 & $"$ & 0.006 & 0.094 \\
\hline B-12 & 0.058 & 0.012 & 0.037 & " & 0.004 & 0.120 \\
\hline B-15 & 0.049 & 0.019 & 0.032 & " & tr. & 0.100 \\
\hline B- 16 & 0.048 & 0.025 & 0.034 & $"$ & $\operatorname{tr}$ & 0.107 \\
\hline $\mathrm{M}-14$ & 0.022 & 0.003 & 0.005 & ” & 0.005 & 0.035 \\
\hline
\end{tabular}

Table 1. Chemical composition and hardness of the representative specimens

\begin{tabular}{|c|c|c|c|c|c|c|c|c|c|c|c|c|c|c|c|c|c|}
\hline \multirow{2}{*}{$\begin{array}{l}\text { Kind of } \\
\text { wares }\end{array}$} & \multirow{2}{*}{$\begin{array}{l}\text { Specimen } \\
\text { No. }\end{array}$} & \multirow{2}{*}{$\begin{array}{c}\text { Name of } \\
\text { temples }\end{array}$} & \multirow{2}{*}{$\begin{array}{c}\text { Age of } \\
\text { manu- } \\
\text { facture }\end{array}$} & \multicolumn{12}{|c|}{ Chemical composition (\%) } & \multirow{2}{*}{$\begin{array}{l}\text { Nonmetallic** } \\
\text { inclusions (\%) }\end{array}$} & \multirow{2}{*}{$\begin{array}{c}\text { Hardness } \\
\text { (VPN) }\end{array}$} \\
\hline & & & & $\mathrm{C}$ & $\mathrm{Si}$ & $\mathrm{Mn}$ & $\mathrm{P}$ & $\mathrm{S}$ & $\mathrm{Cu}$ & $\mathrm{Ni}$ & $\mathrm{Cr}$ & $\mathrm{Ti}$ & $\mathrm{Al}$ & $\mathrm{N}$ & $\mathrm{O}^{*}$ & & \\
\hline \multirow{4}{*}{ Nails } & $\begin{array}{l}\mathrm{H}-1 \\
\mathrm{H}-2 \\
\mathrm{H}-4 \\
\mathrm{H}-5\end{array}$ & Horyuji & $\begin{array}{r}607 \\
1283 \\
1603 \\
1750\end{array}$ & $\begin{array}{l}0.10 \\
0.09 \\
0.25\end{array}$ & $\begin{array}{l}0.004 \\
0.013 \\
0.008\end{array}$ & $\begin{array}{l}\text { tr. } \\
\text { tr. } \\
0.23\end{array}$ & $\begin{array}{l}0.033 \\
0.027 \\
0.018\end{array}$ & $\begin{array}{l}0.004 \\
0.003 \\
0.063\end{array}$ & $\begin{array}{l}0.008 \\
\text { tr. } \\
0.062\end{array}$ & $\begin{array}{l}0.008 \\
0.014 \\
0.016\end{array}$ & $\begin{array}{l}\text { tr. } \\
\text { tr. } \\
0.025\end{array}$ & $\begin{array}{r}<0.010 \\
0.010 \\
<0.010\end{array}$ & $\begin{array}{l}0.010 \\
0.005 \\
0.006\end{array}$ & $\begin{array}{l}0.0035 \\
0.0056 \\
0.0058\end{array}$ & $\begin{array}{l}0.014 \\
0.076 \\
0.009\end{array}$ & $\begin{array}{l}1.72 \\
2.90 \\
0.34 \\
0.86\end{array}$ & $\begin{array}{l}104-169 \\
113-310 \\
142-199 \\
131-317\end{array}$ \\
\hline & $\begin{array}{l}\text { B-1 } \\
\text { B-4 } \\
\text { B-6 } \\
\text { B-9 } \\
\text { B-10 }\end{array}$ & Byodoin & $\begin{array}{c}1053 \\
" \prime \\
" \prime \\
" \prime \\
1670\end{array}$ & $\begin{array}{l}0.35 \\
0.28 \\
0.21 \\
0.45 \\
0.30\end{array}$ & $\begin{array}{l}0.039 \\
0.017 \\
0.043 \\
0.023 \\
0.036\end{array}$ & $\begin{array}{l}0.01 \\
\text { tr. } \\
\text { tr. } \\
\text { tr. } \\
\text { tr. }\end{array}$ & $\begin{array}{l}0.030 \\
0.020 \\
0.026 \\
0.027 \\
0.030\end{array}$ & $\begin{array}{l}0.003 \\
0.003 \\
0.003 \\
0.002 \\
0.002\end{array}$ & $\begin{array}{l}0.007 \\
0.014 \\
0.059 \\
0.011 \\
0.018\end{array}$ & $\begin{array}{l}0.010 \\
0.009 \\
0.022 \\
\overline{-} \\
0.007\end{array}$ & $\begin{array}{l}0.008 \\
0.004 \\
0.003 \\
0.002 \\
0.009\end{array}$ & $\begin{array}{l}\text { tr. } \\
0.009 \\
0.040 \\
0.059 \\
0.044\end{array}$ & $\begin{array}{c}0.006 \\
0.018 \\
- \\
\overline{-} \\
0.003\end{array}$ & $\begin{array}{l}0.0063 \\
0.0040 \\
0.0055 \\
\overline{0} \overline{0053}\end{array}$ & $\begin{array}{l}0.043 \\
0.210 \\
0.230 \\
-190\end{array}$ & $\begin{array}{l}1.46 \\
1.45 \\
1.40 \\
0.80 \\
1.49\end{array}$ & $\begin{array}{r}109-120 \\
120-169 \\
105-177 \\
145-204 \\
80-243\end{array}$ \\
\hline & $\mathrm{M}-1$ & Meitsuji & $1450 \sim$ & 0.08 & 0.123 & 0.01 & 0.049 & - & 0.010 & - & - & - & - & - & - & - & $130-161$ \\
\hline & $\begin{array}{l}\text { D-1 } \\
\text { D-2 } \\
\text { D- } 6\end{array}$ & Daigoji & $\begin{array}{c}953 \\
\stackrel{\prime \prime}{\prime} 1772\end{array}$ & $\begin{array}{l}0.24 \\
0.26 \\
0.45\end{array}$ & $\begin{array}{l}0.050 \\
0.070 \\
0.046\end{array}$ & $\begin{array}{l}\operatorname{tr} \\
\text { tr. } \\
\text { tr. }\end{array}$ & $\begin{array}{l}0.013 \\
0.019 \\
0.059\end{array}$ & $\begin{array}{l}0.009 \\
0.001 \\
0.003\end{array}$ & $\begin{array}{l}\text { tr. } \\
0.020\end{array}$ & $\begin{array}{l}\text { tr. } \\
\text { tr. } \\
0.001\end{array}$ & $\begin{array}{l}\text { tr. } \\
\text { tr. } \\
0.003\end{array}$ & $\begin{array}{l}\mathrm{tr} . \\
\text { tr. } \\
0.061\end{array}$ & $\begin{array}{l}- \\
-\end{array}$ & $\overline{\bar{z}}$ & $\begin{array}{l}- \\
-\end{array}$ & $\frac{-}{1.63}$ & $110-\overline{-} 63$ \\
\hline \multirow[t]{2}{*}{ Clamps } & $\begin{array}{l}\text { B- } 12 \\
\text { B- } 15 \\
\text { B-16 }\end{array}$ & Byodoin & $\begin{array}{l}1053 \\
1670 \\
1906\end{array}$ & $\begin{array}{l}0.26 \\
0.02 \\
0.02\end{array}$ & $\begin{array}{l}0.024 \\
0.142 \\
0.154\end{array}$ & $\begin{array}{l}\text { tr. } \\
0.010 \\
0.010\end{array}$ & $\begin{array}{l}0.013 \\
0.258 \\
0.489\end{array}$ & $\begin{array}{l}0.002 \\
0.007 \\
0.047\end{array}$ & $\begin{array}{l}0.012 \\
0.007\end{array}$ & $\begin{array}{l}0.017 \\
0.060 \\
0.007\end{array}$ & $\begin{array}{l}0.002 \\
0.026 \\
0.043\end{array}$ & $\begin{array}{l}0.053 \\
\text { tr. } \\
0.008\end{array}$ & $\begin{array}{l}0.008 \\
0.013 \\
0.037\end{array}$ & $\begin{array}{l}0.0056 \\
0.0035 \\
0.0050\end{array}$ & $\begin{array}{l}0.230 \\
0.122 \\
0.408\end{array}$ & $\begin{array}{l}1.62 \\
2.23 \\
4.92\end{array}$ & $\begin{array}{l}94-152 \\
118-160 \\
147\end{array}$ \\
\hline & M-14 & Meitsuji & $1450 \sim$ & 0.07 & 0.009 & 0.008 & 0.076 & 0.004 & 0.012 & 0.021 & & 0.020 & 0.004 & 0.0039 & 0.200 & 3.38 & $117-274$ \\
\hline Rivets & $\begin{array}{l}\text { B-17 } \\
\text { B-18 }\end{array}$ & Byodoin & $\underset{n}{1670}$ & 0.07 & 0.049 & 0.010 & 0.040 & - & 0.012 & 0.039 & 0.008 & $\operatorname{tr}$. & 0.001 & & & $\begin{array}{l}0.67 \\
0.50\end{array}$ & $\begin{array}{r}128-239 \\
92-102\end{array}$ \\
\hline \multirow{2}{*}{$\begin{array}{l}\text { Decora- } \\
\text { tive } \\
\text { fittings }\end{array}$} & $\begin{array}{l}\text { M-16-A } \\
\text { M-16-B } \\
\text { M-17 }\end{array}$ & Meitsuji & $\begin{array}{l}1450 \sim \\
\prime \prime \\
1701\end{array}$ & $\begin{array}{r}0.08 \\
<0.10 \\
<0.10\end{array}$ & $\begin{array}{l}0.052 \\
0.047 \\
0.123\end{array}$ & $\begin{array}{l}0.006 \\
0.013 \\
0.012\end{array}$ & $\begin{array}{l}0.085 \\
0.085 \\
0.049\end{array}$ & $\begin{array}{l}0.011 \\
0.013\end{array}$ & $\begin{array}{l}0.009 \\
0.018 \\
0.010\end{array}$ & $\begin{array}{l}0.019 \\
0.024\end{array}$ & & $\begin{array}{l}0.013 \\
\text { tr. }\end{array}$ & $\begin{array}{l}- \\
-\end{array}$ & E & & $\begin{array}{l}\frac{1.03}{-} \\
3.55\end{array}$ & $\begin{array}{r}110-135 \\
110-157 \\
97-104\end{array}$ \\
\hline & $\begin{array}{l}\text { M-18 } \\
\text { M-19 }\end{array}$ & Meitsuji & $\begin{array}{l}1450 \\
1450 \sim\end{array}$ & $\begin{array}{l}4.60 \\
4.13\end{array}$ & $\begin{array}{l}0.059 \\
0.051\end{array}$ & $\begin{array}{l}0.033 \\
0.030\end{array}$ & $\begin{array}{l}0.132 \\
0.207\end{array}$ & $\begin{array}{l}0.022 \\
0.033\end{array}$ & $\begin{array}{l}0.018 \\
0.079\end{array}$ & $\begin{array}{l}0.016 \\
0.010\end{array}$ & - & $\begin{array}{l}0.020 \\
0.010\end{array}$ & - & - & - & - & $\begin{array}{l}502-509 \\
494-540\end{array}$ \\
\hline
\end{tabular}

* Vacuum fusion method.

** JIS point-counting method. 

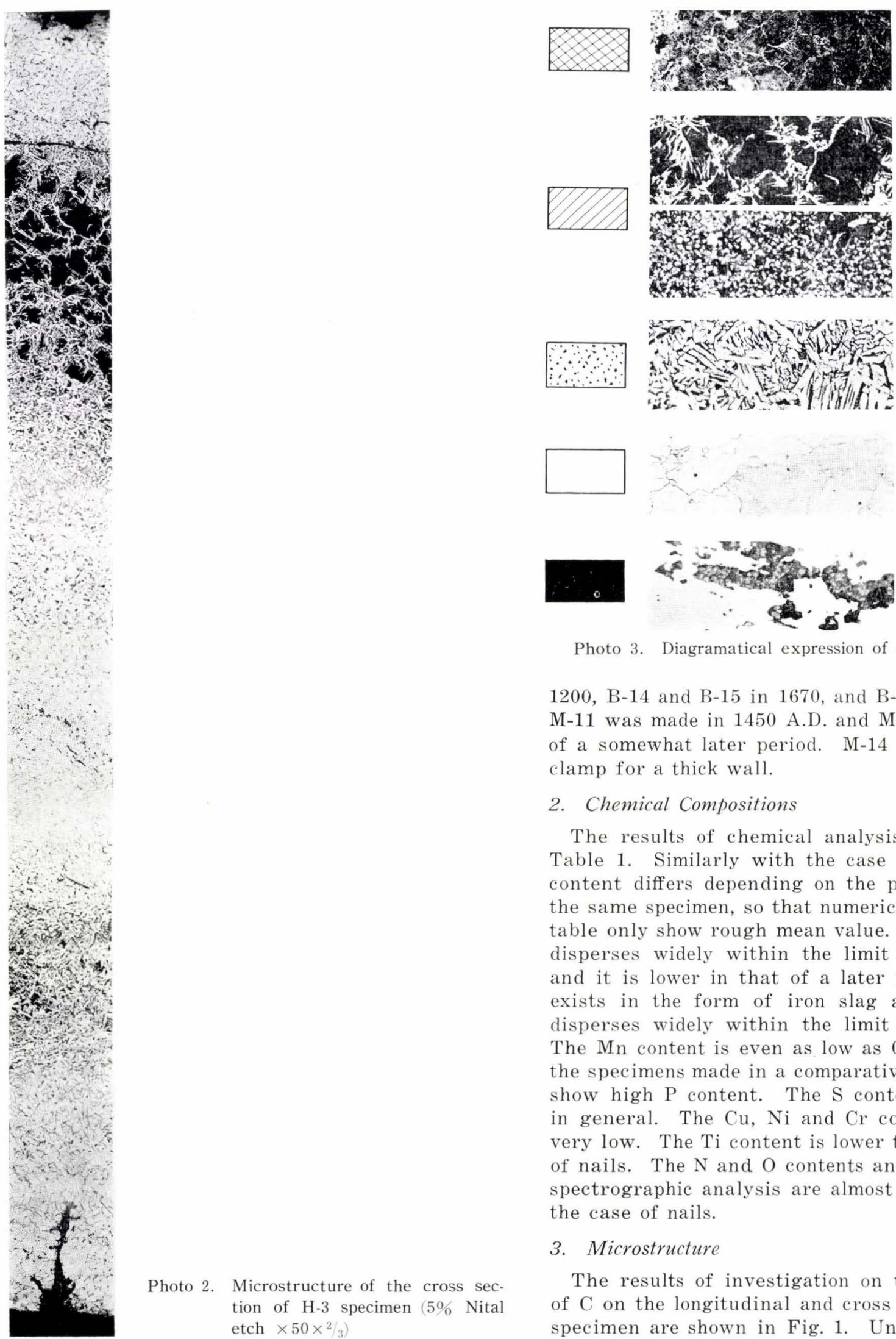
C $>0.5$
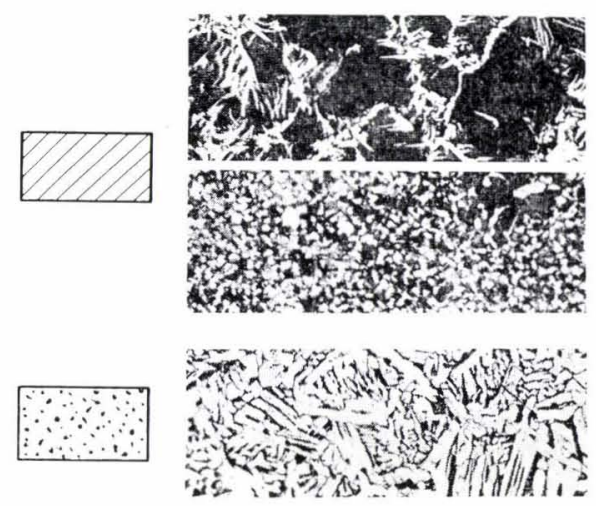

0. $4>C>0.2$

$\mathrm{C}<0.1$
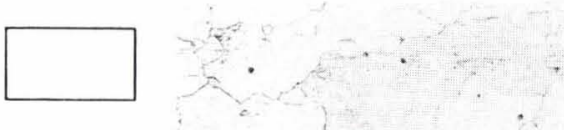

C $<0.1$ (coarse grain
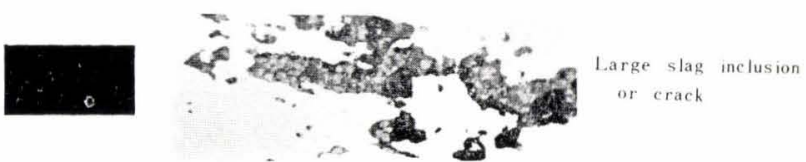

Photo 3. Diagramatical expression of carbon content

$1200, \mathrm{~B}-14$ and B-15 in 1670, and B-16 in 1906 A.D. M-11 was made in 1450 A.D. and M-12 M-14 were of a somewhat later period. M-14 is a large-sized clamp for a thick wall.

\section{Chemical Compositions}

The results of chemical analysis are shown in Table 1. Similarly with the case of nails, the C content differs depending on the position even in the same specimen, so that numerical values in the table only show rough mean value. The $\mathrm{C}$ content disperses widely within the limit of $0.008-0.15 \%$. and it is lower in that of a later period. The Si exists in the form of iron slag and its content disperses widely within the limit of $0.009-0.15 \%$. The Mn content is even as low as $0.01 \%$. Some of the specimens made in a comparatively later period show high $\mathrm{P}$ content. The $\mathrm{S}$ content is very low in general. The $\mathrm{Cu}, \mathrm{Ni}$ and $\mathrm{Cr}$ contents are also very low. The Ti content is lower than in the case of nails. The $\mathrm{N}$ and $\mathrm{O}$ contents and the results of spectrographic analysis are almost the same as in the case of nails.

\section{Microstructure}

Photo 2. Microstructure of the cross section of $\mathrm{H}-3$ specimen $(5 \%$ Nital etch $\times 50 \times 2 / 3$ )

The results of investigation on the distribution of $\mathrm{C}$ on the longitudinal and cross section of each specimen are shown in Fig. 1. Unevenness in the 
$\mathrm{H}-3$ 6 - 10 50 ?

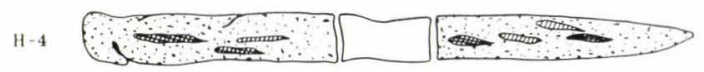

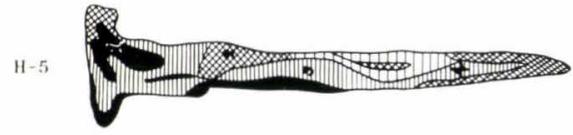

$\square \square \square$

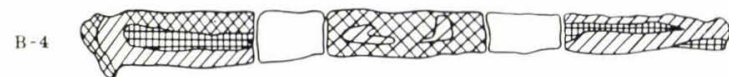

B-6 एव $\square$

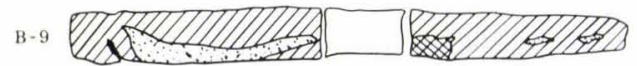

B- 10

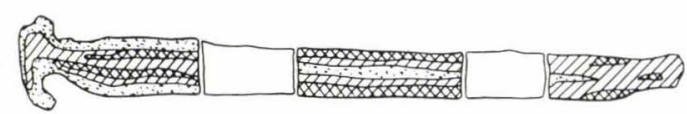

M-

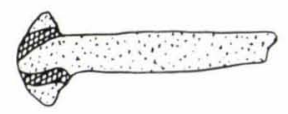

D-1

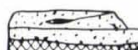

$\quad 2 \quad 0 \quad 0 \quad 0$ (

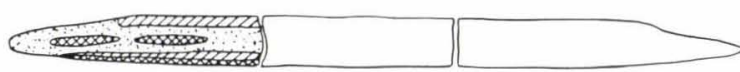

D-6
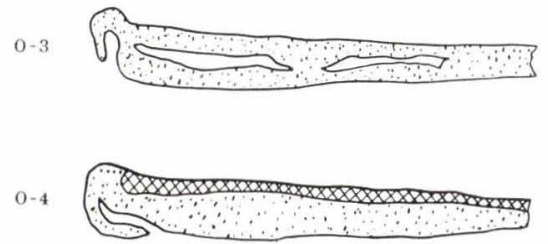
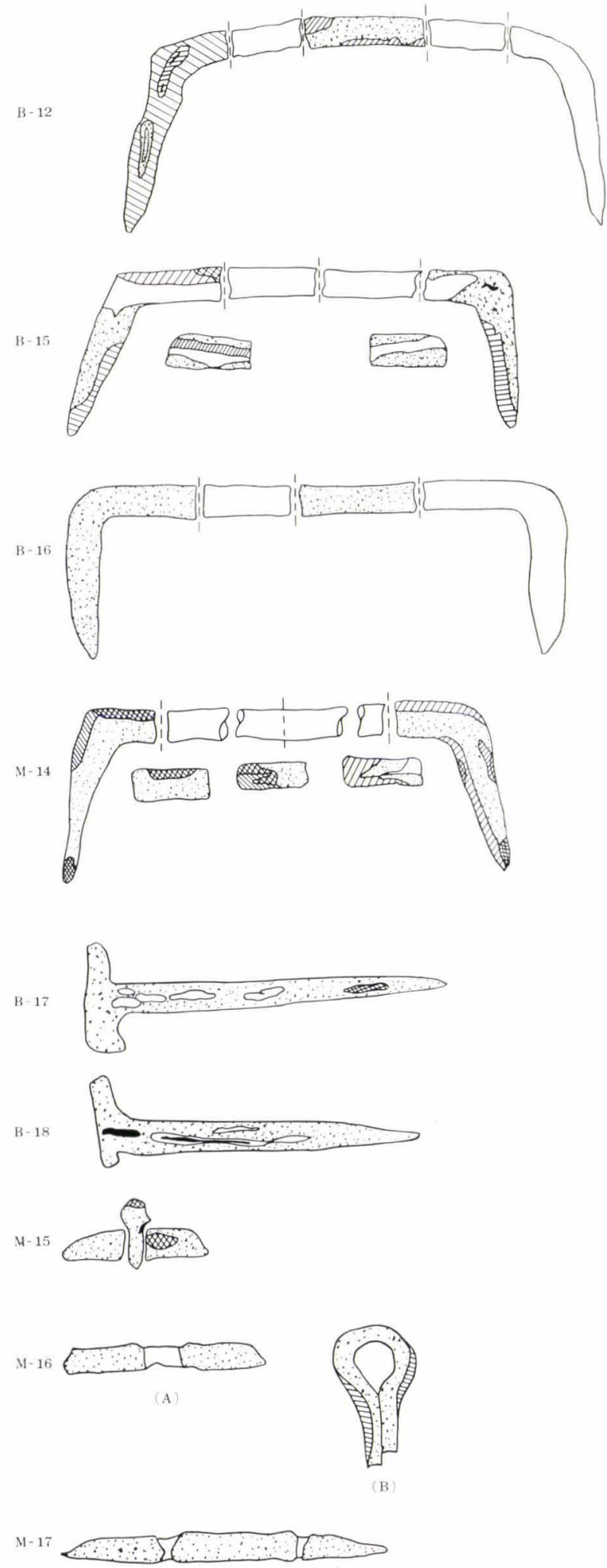

Fig. 1. Carbon distribution of longitudinal and cross section of the representative specimens 


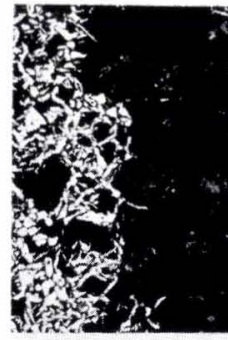

(1)

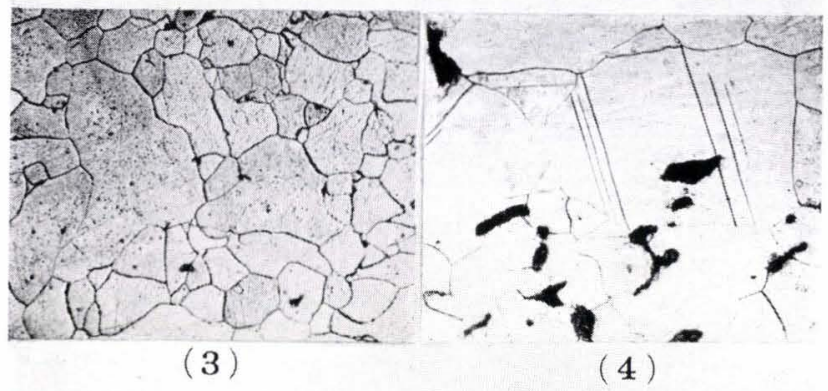

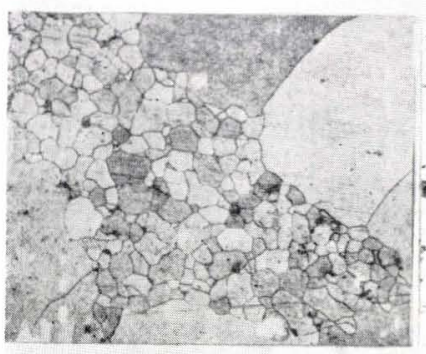

(5)

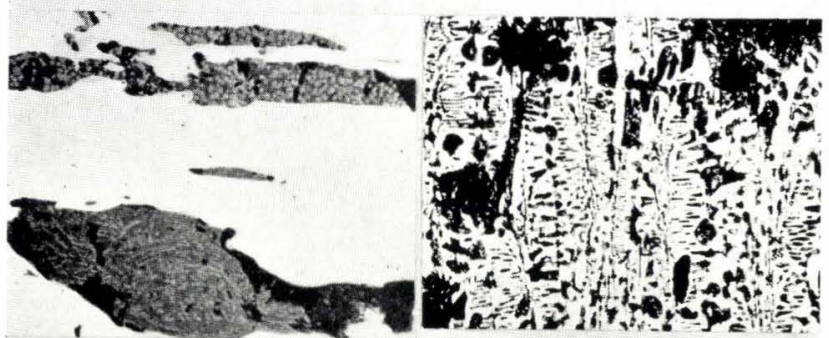

( 7 )

(8)

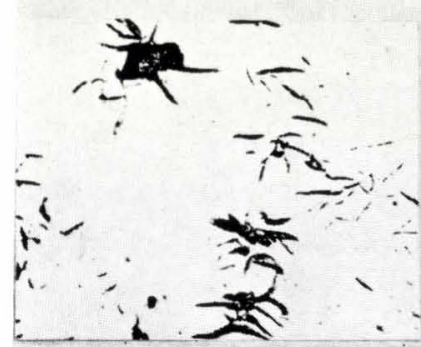

(9)

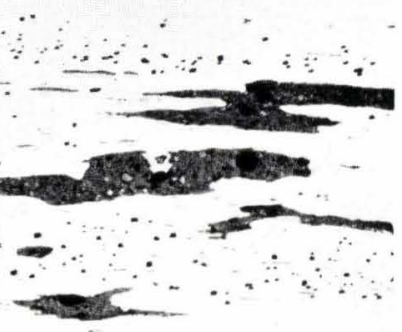

(6)

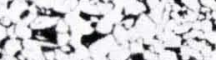

(2)

\footnotetext{
(1) (2) (3): Structure of steel specimen H-3

4): $\quad$ Structure of specimen B-15

Structure of specimen B-17

Slag inclusions of specimen B-16

Slag inclusions of specimen $\mathrm{H}-3$

Structure of cast iron specimen M-18

$((8)$ is etched and $(9)$ is no-etched.)
}

Photo 4. Typical microstructure of specimens $(\times 100 \times 2 / 3)$ structure was found in the products of the older period. Those of large size were similar to the old nails, while in B-16 of the newer product a comparatively homogeneous structure is found irrespective of its comparatively large size. It is considered that, owing to the development in manufacturing techniques, a large-sized product was obtained without forging crude iron. M-13 and M-14 show a shape indicating an outside layer of high-C steel. But it is supposed to have been made by chance.

\section{Nonmetallic Inclusions}

Slag content is very much similar to the case of the old nails. The results of measuring the area ratio by point-counting method are shown in Table 1. In the low-carbon specimen there is found a trend of much quantity of nonmetallic inclusions. Similarly to the case of old nails, nonmetallic inclusions exist comparatively much in the low-carbon part and near the welding zone by forging with the same specimen. It is mainly composed of iron silicate similar to that of the old nails. B-16 is one of the most recently produced specimens, but judging from its much nonmetallic inclusions, it was not made by a modern steelmaking methods.

Almost the same tendency is found in the clamp taken from "Meitsuji" temple. The results of chemical analysis are shown in Table 2 .

\section{Hardness}

Because of unevenness in its microstructure, there was naturally a dispersion in hardness. The results of measuring hardness are shown in Table 1.

\section{Rivets}

\section{Specimens Investigated}

Three specimens (B-17 to B-19) taken from the "Hoodo" (sanctuary) of "Byodoin" temple were produced in 1670 A.D. Their outside appearances are shown in Photo 1 . The head of B-17 is recognized to have been bound to the trunk part by forging.

\section{Chemical Compositions}

The results of chemical analysis of the rivets are shown in Table 1. They are pure just as the nails and clamps and are low in impurities, especially in Mn and S. The results of spectrographic analysis have shown that there existed almost no other alloying elements.

\section{Microstructure}

The results of investigating $\mathrm{C}$ distribution in the longitudinal cross section are shown in Fig. 1. Its structure is comparatively homogeneous perhaps 
because of its small shape. Coarse ferritic grains extending over the central part and the head part of the trunk and slip lines are also recognized.

\section{Nonmetallic Inclusions}

Iron slag is fine and lengthened by forging and its quantity is also comparatively small. The results of measuring the area ratio by the pointcounting method are shown in Table 1.

\section{Hardness}

The results of measuring hardness are shown in Table 1. There is no unevenness in hardness because of its comparatively homogeneous structure.

\section{Decorative Iron Fittings}

\section{Specimens Investigated}

Five specimens taken from the three-story pagoda of "Meitsuji" temple were presented for the investigation. M-15 and M-16 are presumed to have been made in about 1450 A.D. or somewhat later. M-15 is an iron fitting of washer shape and has a hole in its center to fasten it with a short nail. M-16-A is a fitting of washer shape with flowered patterns and M-16-B is a fitting of ring. M-17 was manufactured in 1701 A.D. and has two holes to fasten it with binding nails. M-18 and M-19 which are presumed to have been made in 1450 A.D. or somewhat later are pieces of cast iron.

\section{Chemical Composition}

The results of chemical analysis are shown in Table 1. Chemical compositions of steel products M-15 to M-17 are almost the same as those of nails, clamps and rivets. It has been found that both M18 and M-19 are somewhat higher in C, somewhat lower in $\mathrm{P}$, and are very low in $\mathrm{Si}, \mathrm{Mn}$ and $\mathrm{S}$ compared with present-day cast iron. Other alloying elements are only slight in quantity. It is considered that iron sand has been used for them as raw material.

\section{Microstructure}

Distribution of $\mathrm{C}$ is shown in Fig. 1. The $\mathrm{C}$ distribution in steel products is almost the same as in nails, clamps and rivets. The cast iron has the structure of white pig iron as shown in Photo 3.

\section{Nonmetallic Inclusions}

The results of measuring the area ratio by the point-counting method are shown in Table 1 . The quantity of nonmetallic inclusions is generally high in the specimen perhaps due to its low-carbon content. And it has been found that, judging from their way of flow, holes in M-15 and M-17 were punched from the back and the hole in M-16-A was punched from the surface,

\section{Hardness}

The results of measuring the hardness of each specimen are shown in Table 1.

\section{Correlation with the Age of Manufacture}

\section{Shape}

Nails manufactured in the later age give us impression of being delicate with their long and slender shapes, but on the other hand, clamps are of a broader and stronger shape. The later the age of manufacturing, the bigger the head of the nails is.

\section{The Way of Manufacture}

The specimens were manufactured by forging several kinds of crude steel of different carbon content, but the older the age of manufacturing is, the more numerous the crude steels used. The specimen of the later age was manufactured from one kind of crude steel even in a comparatively large size, but it was not presumed to have been produced by a modern steelmaking method because of its high nonmetallic inclusions.

\section{Chemical Compositions}

Regardless of the age of their manufacture, almost no $\mathrm{Mo}, \mathrm{Co}, \mathrm{Sn}, \mathrm{Pb}, \mathrm{V}, \mathrm{Ag}, \mathrm{As}$ and $\mathrm{Zn}$ is evident and the quantity of other alloying elements is very slight. These chemical compositions agree favorably with the results of investigation on "Old Japanese Swords"1) by Dr. K. Tawara and on "Nails".2) by Dr. Nishimura or with the report on nails in Europe ${ }^{3)}$. The specimens manufactured in about 600 A.D. are especially pure.

In the case of nails the $\mathrm{C}$ content has no relation to the period of manufacture, but the $\mathrm{C}$ content of clamps, rivets and others is somewhat lower in proportion to the later period. The Si which exists as iron slag disperses widely depending on specimens. No correlation with the age of their manufacture has been found. The $\mathrm{Mn}$ is very low such as under $0.01 \%$, but some specimens made later than in 1500 A.D. show a higher value. This indicates some other raw materials than iron sand were also used. It was recognized that the $\mathrm{P}$ content in the specimens manufactured before about 1400 A.D. was less than $0.03 \%$, but almost all of those manufactured later than 1500 A.D. have shown more than $0.03 \%$. Some clamps manufactured after 1700 A.D. have shown a very high $\mathrm{P}$ content such as 0.3 to $0.5 \%$.

The $\mathrm{S}$ content is also very low, but a somewhat higher $\mathrm{S}$ is found in those of later age. The $\mathrm{Cu}$ is under $0.02 \%$ in general, but some nails have 0.06 to $0.08 \% \mathrm{Cu}$. Almost no relation to the age of their manufacture was recognized in the contents of $\mathrm{Ti}$, 
$\mathrm{Al}, \mathrm{N}$ and $\mathrm{O}$. Nonmetallic inclusions are rather increased in those of the later age.

\section{Microstructure and Hardness}

In those manufactured in the older age, there exist many parts of different $\mathrm{C}$ content even in the same specimen but the later the age of manufacture, the less the number and the more homogeneous the structure. Consequently, unevenness is found in hardness in the older specimens.

\section{Conclusion}

The results of metallurgical investigations on the nails, clamps, rivets and decorative iron fittings manufactured between 607 and 1900 A.D. are as follows.

(1) These products are very low in $\mathrm{Mn}, \mathrm{S}$ and $\mathrm{Cu}$ in general and are presumably made of wrought iron using sand iron as a raw material.

(2) There are some specimens, with nearly the same content of $\mathrm{Mn}$ and $\mathrm{S}$ as in steel used at present, which are considered to have been manufactured from iron ore not from iron sand.

(3) Other alloying elements are extremely slight excepting two or three specimens of high $\mathrm{P}$, but the iron slag content is very high.

(4) Even in the same specimen, the C content is remarkably different depending upon the position and consequently, unevenness in hardness is also noticeable. This unevenness is remarkable in the older specimens, but a uniform hardness is found in the newer specimens.

(5) In cast iron products, the $\mathrm{C}$ content is somewhat higher, the $\mathrm{P}$ is somewhat less and Si, Mn and $\mathrm{S}$ are noticeably lower than the cast iron used at present.

(6) Correlation of the quality of specimens and the age of their manufacture could not be determined so clearly because there was a considerable dispersion of chemical composition in specimens manufactured in the same age.

\section{Acknowledgement}

The authors would like to express their thanks to Mr. Yoshimichi Emoto of the Department of Conservation of Tokyo Institute of Cultural Properties, who gave the authors instructions for conducting this investigation.

\section{REFERENCES}

1) K. Tawara: Scientific Study on Japanese Swords Made in Japan, Maruzen, Tokyo (1953).

2) H. Nishimura et alius: Tetsu-to-Hagané, 41 (1955), 289.

3) C. A. Zapffe: Wire and Wire Product, 30 (1955), 1500. 